features, which seemed to be mainly reactive to the condition as perceived by the patient. None of the depressed patients denied their disability, and intellectual loss was slight or absent. The same incidence of depression was found in the patients with muscular dystrophy, emphasizing the extent to which the affective change is an understandable reaction to physical disability. On the other hand, the classical euphoria was highly significantly correlated with intellectual loss and denial of disability.

Established cases of multiple sclerosis thus frequently show evidence of organic dementia - as indeed would be expected from neuropathological studies such as those by B. Brownwell and J. T. Hughes. ${ }^{3}$ How early these psychological changes might occur cannot be deduced from the Oxford studies, since patients were examined only once and well on in the disease, nor could the authors say whether these changes might fluctuate with time, as the physical symptoms do in some cases.

The importance of these findings lies in their relationship to rehabilitation and retraining. The degree of organic psychological dilapidation is a strong limiting factor for the success of rehabilitation. In particular, patients who are obviously euphoric should be regarded as probably demented unless proved otherwise, and hope for successful rehabilitation must be appropriately guarded.

\section{Front-seat Hazards}

Windscreens are made of either laminated or toughened glass. The laminated sort is also known as safety glass, but it has the dangerous characteristic of breaking with sharp edges, spikes, and corners. Toughened glass has the disadvantage that impact may cause the whole screen to craze and become opaque, but when it breaks it forms small, roughly cubical fragments with much less formidable cutting power than the broken edge of "safety" glass. Nevertheless, it can do enough damage to require several hours of patient and painstaking trimming and stitching on the face and forehead. The fragments sometimes become embedded and they have also been inhaled, but from Australia ${ }^{1}$ comes an account of five examples of deep penetration of the frontal region of the brain by pieces of glass from toughened windscreens. The authors did not find any previous reports of this dramatic injury, which they think occurred when the face was driven downwards on to the edge of the glass that had already been broken by the forehead. These injuries underline the importance of impressing on the junior staff of accident and emer-

\footnotetext{
Rushworth, R. G., and Toakley, J. G., Medical fournal of Australia $1969,2,80$.

- Guthkelch, A. N., British Medical fournal, 1960, 2, 842

Bard, L. A., and Jarrett, W. H., Archives of Ophthalmology, 1964, 71, 332.

Ziperman, H. H., and M6Ginty, J. B., fournal of Trauma, 1964, 4, 400 .

- Widman, J. C., communication to the mid-year meeting of the Society of Automotive Engineers (Chicago May 17-21, 1965). New York.

- Gissane, W., and Bull, J. P., 1965. Fifth annual progress report. Road injuries research group. Birmingham.

1 Wade, P. A., Fournal of Bone and foint Surgery, 1961, 43B, 634.

Gissane, W., and Bull, J. P., 2nd annual progress report R.I.R.G. Birmingham, 1962.

- Registrar-General's Report for England and Wales, 1967. London, H.M.S.O., 1968.

10 Gissane, W., Annals of the Royal College of Surgeons of England, $1962,30,281$.

"1 Sube, J., Ziperman, H. H., and McIver, W. J., American fournal of Surgery, 1967, 113, 346.

12 Smith, W. S., and Kaufer, H., Fournal of Bone and Foint Surgery, 1969, 51A, 239.
}

gency departments the fact that any wound caused by more than moderate violence may have led to surprisingly large and unexpected foreign bodies being deeply embedded through disproportionately small openings. This does not apply only to the head or to road accidents. ${ }^{2-4}$ Intelligent suspicion that is not allayed by suitable radiographic examination demands carefully planned exploration.

Manufacturers are well aware of the dangers and shortcomings of toughened and safety glass. One way to overcome the dangers of the broken screen is to make it capable of being ejected intact on impact, another is to increase the thickness of the intermediate layer of laminated glass so as to increase its resistance to penetration by allowing it to bulge on impact. ${ }^{5}$

Dangerous as the windscreen may be it is only one of the causes of injury of the face and head in vehicles. W. Gissane and J. P. Bull ${ }^{6}$ found that of 216 persons killed while occupying the front seats 31 had been injured by the windscreen, 40 by the roof, and 106 by the dashboard and related parts. The head may also be injured by contact with other parts of the vehicle and when the occupants are thrown out. ${ }^{7}$ They found also that $21 \%$ of the occupants of the front seats were injured by contact with the windscreen and its surrounding ${ }^{8}$ and that $63 \%$ of drivers and $72 \%$ of other occupants of front seats had severe injury of the brain. ${ }^{6}$ The full importance of head injuries in vehicles is more clearly shown by the official record that injuries of the skull and associated parts accounted for $44 \%$ of the 2,666 fatal accidents. ${ }^{9}$

The lesson is clear, but it is still ignored by the $75 \%$ or so of motorists who either do not have or do not use seat belts. The arguments against them break down in the face of the clear evidence ${ }^{8}{ }^{10-12}$ that safety belts very rarely cause serious injury if they restrain the upper part of the trunk as well as the hips, if they are correctly fitted in the vehicle, and if they are not only worn but correctly worn on all journeys, however short and at however low speeds.

\section{Diagnostic Tests for Advanced Cancer}

A single test on blood or urine that will confirm or exclude the presence of cancer anywhere in the body is nowadays regarded as a pipe dream. Tumours of different sites differ too widely to allow the detection of a common feature distinguishable in patients with cancer but not in persons without. Nevertheless the increasing availability of methods for rapidly measuring levels of normal and abnormal constituents of blood and urine, together with computerized data-processing equipment, suggests that it may be timely to look again-not for a single, all-embracing test but for associations between patterns of normal and abnormal constituents and neoplasms of specific types.

There are several different reasons why abnormalities in body fluids may be associated with cancers. Unusual proteins may be the result of neoplastic transformation by viral or chemical agents. Foetal antigens may reappear in undifferentiated tumours. Poorly vascularized tumours may provide a suitable breeding-place for a variety of passenger organisms, and these, non-specifically, may give rise to abnormal constituents in the blood and urine. Necrosis of 
neoplastic tissue, either spontaneously as a result of poverty of blood supply or as a consequence of therapy, may lead to the release of otherwise cell-bound proteins. Tissuespecific proteins may be released when normal structures are invaded and destroyed by a growing tumour. Tumour tissue itself may, because it has an unusual complement of enzymes, be a source of unusual metabolites. Tumours of endocrine glands may secrete excessive amounts of particular hormones, and the cells of tumours of non-endocrine tissues, such as the bronchial mucosa, may secrete hormones such as A.C.T.H. Drugs given to treat symptoms related or unrelated to cancer may give rise to unusual metabolites or induce enzymes that alter normal metabolic processes. Inanition due to anorexia or peculiarities of diets may change the spectrum of constituents of blood and urine. Metastatic deposits in the liver may interfere with normal metabolism. The nature and extent of abnormalities may change either as a result of the tumour's progression $^{1}$ or because a particular type of tissue is destroyed for the first time.

It is against this background that a recent paper by $D$. Rudman and his colleagues ${ }^{2}$ in New York should be viewed. In a study of 56 patients with 19 different types of advanced disseminated malignant disease they recorded 27 in whom the daily output in the urine of four unusual peptides was 2 to 8 times greater than normal. Nine patients showed, in addition, a significant output (3-28 $\mathrm{mg}$. per day) of proteins in the 12,000 to 50,000 molecular weight range-that is, smaller than albumin. Electrophoresis indicated the presence of 25 different proteins of low molecular weight in these nine urines. Four of the proteins were seen in urine from more than one patient. The authors make no exaggerated claims with regard to the diagnostic value of the tests they have used, but they do point out that, with the exception of cases of multiple melanoma, unusual peptides and proteins of low molecular weight were more or less confined to patients destined to die within six months. Among cancer patients without abnormal urinary peptides or proteins $87 \%$ survived longer than this.

None of the proteins and only one of the peptides-a glycopeptide-studied by Rudman and his colleagues appeared to match substances found by others in urine from normal persons, ${ }^{3-11}$ and only four of them reacted with rabbit antiserum to normal human serum. It is possible that future studies will show that some of the proteins are the same as those previously found in particular organs such as brain, kidney, or prostate but not in serum. ${ }^{1213}$ It is already clear

1 Foulds, L., Cancer Research, 1954, 14, 327.

2 Rudman, D., del Rio, A., Akgun, S., and Frumin, E., American Fournal of Medicine, 1969, 46, 174.

3 Heremans, M. T., Vaerman, J. P., and Heremans, J. F., in Protides of the Biological Fluids, ed. H. Peetess, 1960, p. 396." Amsterdam,
Elsevier.

4 Berggard, I., Cleve, H., and Bearn, A. G., Clinica Chimica Acta, 1964,

Tamm, I., and Horsfall, F. L., fournal of Experimental Medicine, $1952,95,71$.

- Valardi, D. P., Cifonelli, J. A., and Dorfman, A., Biochimica et Biophysica Acta, 1967, 141, 103.

Heremans, J. F., Vaerman, J. P., and Heremans, M. T., Nature, 1959, $183,1606$.

Hakomori, S., and Ishimoda, T., fournal of Biochemistry, 1962, 52, 250.

Miettinen, T. A., Scandinavian Fournal of Clinical and Laboratory Investigation, 1962, 14, 380.

$57,129$.

11 Miettinen, T. A., Clinica Chimica Acta, 1963, 8, 693.

12 Grant, G. H., Fournal of Clinical Pathology, 1959, 12, 510.

13 Laterre, E. C., Heremans, J. F., and Carbonara, A., Clinica Chimica Acta, 1964, 10, 197.

14 Smiley, J. D., and Ziff, M., Physiological Reviews, 1964, 44, 30.

15 Cunningham, L. W., Ford, J. D., and Segrest, J. P., Fournal of Biological Chemistry, 1967, 242, 2570. that none of the peptides corresponds to known derivatives of collagen. $^{14} 15$

As Rudman and his colleagues point out, "much additional work will be needed before the origin and significance of these substances will become clear," But it should perhaps at this stage be regarded as more likely that they are relatively non-specific products of tissue destruction than "specific products, possessing structural, enzymatic or other physiologic function, of the proliferating malignant cell type." In the meantime these observations may find an application in prognosis.

\section{A Load of Tripe}

The report issued this week by the University Grants Committee $^{1}$ is remarkable for the terms it uses to enumerate undergraduate and postgraduate students. In some of its tables columns of figures giving numbers of undergraduates are headed " Undergraduate student load," while those alongside them dealing with postgraduates are headed " Postgraduate student numbers." The distinction arises because the undergraduates " are apportioned to subject-groups according to the teaching load they impose" on departments rather than according to their main subject of study.

To be reduced to a number is an unobjectionable fate to which we are all accustomed at the hands of the Registrar General when we are born, marry, or die. And no one but a professional curmudgeon objects to being enumerated for the good, or at least the justifiable curiosity, of the community. But to be lumped together as simply a "load" is surely something new. A load of what ? Politeness forbids several possible guesses, and the reader may be left with the conclusion that this unhappily chosen term has become a piece of almost meaningless jargon, though from somewhere behind the arras comes the groan of distinguished professors at the "teaching load" they have to endure.

In several places even the postgraduates are piled up in a general "student load," and a statistician has introduced a farcical note at the foot of one table in solemnly announcing that "the postgraduate load is unweighted." The casual reader might be forgiven for wondering whether the University Grants Committee knows that it is dealing with men and women.

\section{Clinical Progress}

This week we start publication of a new series of articles called "Clinical Progress." The emphasis of these short symposia will be on recent advances in fields of broad general interest, considered from several different aspects. For example, this week's symposium on peptic ulcer includes contributions on diagnosis, medical management, and surgical treatment; future topics include asthma, jaundice, and pulmonary embolism. The series is intended to help students and junior doctors preparing for examinations, but it should also interest those working in other specialties who wish to keep up to date.

1 Un:versity Grants Committes, Statistics of Education: Universities. London, H.M.S.O. £2 2s. 6d. net. 